\title{
NEWPIN: an opportunity for positive change
}

\author{
Myra Gurr and Anne Hansen
}

The work of NEWPIN was pioneered in the London Borough of Southwark in 1982. It was influenced by the rising child abuse figures, which were higher than the national average, and the low take-up of ante- and postnatal services in the district. A study of mothers with young children in Camberwell (Brown \& Harris, 1978) had revealed that there was a high incidence of maternal depression within the group. This also influenced the direction NEWPIN was to take.

The original aims of NEWPIN were to improve the mental health and self-esteem of mothers and thus to reduce child abuse (Pound, 1990). After 13 years of successful practice (Pound, 1994), NEWPIN now focuses upon the minimisation of emotional damage to children and their parents since this is the likely prelude to emotional, physical and sexual harm. The service has been evaluated; two-thirds of women were found to be depressed, and a high rate of background and current adversity was found in women referred.

A NEWPIN centre provides a safe, stable environment, available from 9am to $5 \mathrm{pm}$ five days a week, for mothers and their children. There is also a 24-hour supportive network encompassing the total centre membership throughout the year.

Each referred member who takes up NEWPIN has chosen to try to change the destructive life patterns which affect both her and the well-being of her child. It is in NEWPIN that a mother learns to acknowledge her child's right to safe autonomy through a secure and loving environment provided primarily through her own emotional maturation.

The NEWPIN centre offers a mother and her child an opportunity to form lasting attachments with other mothers and children (Pound, 1990). There is a living room comfortably designed to help members to feel at ease. Through the communal use of the living room, ambivalent and hostile reactions can be contained and worked through. The juxtaposition of the playroom to the living room is a crucial component in NEWPIN. It allows the child to explore and discover new relationships in her or his own timescale, but without fear of premature separation from the mother. This observance of the child timescale is an important aspect of NEWPIN practice but significantly so if the child has an ambivalent attachment to the mother - a common feature of NEWPIN referrals.

When the time is right for herself and her child, the mother will participate in the therapeutic support group, which will then continue throughout her time in NEWPIN. An important part of the process is the modular Personal Development Programme which reflects the anticipated stages of growth a mother will experience during her involvement with NEWPIN. The programme encourages the mother to value herself as a parent and a person; to form a creative and loving relationship with her child; to develop communicating and supportive skills toward others; and 'Learning for Life', the fourth module, equips her for the world of further education or work. The approach which NEWPIN adopts is the promotion of parental growth and development, but without jeopardising the parent/child bond or the child's right to safe autonomy (Jenkins, 1996).

The experiences within Myra's story have resonance for many mothers referred to NEWPIN. As her story unfolds, it will become clear how distressing and damaging early life experiences can adversely affect the capacity to mother, and in Myra's case what mechanisms NEWPIN offered to facilitate change.

Her story illustrates the unreal and idealised expectations that are put upon the child to give unconditional love, which may well have been denied to the mother in childhood. Also negattve identification with the baby and anger at the infantile demands that were never met for the mother. Her story also demonstrates Myra's positive step to decide to change. The testingout of the system as well as NEWPIN's ability to cope with dangerous behaviour, resulting in the breaking of old patterns of behaviour and establishment of new ones through friendship and support. As a result of this, she is able to learn the value of the acceptance of imperfections, the toleration of others, and has been able to use her gains for the benefit of others. 


\section{Myra's story}

My life changed when I first started using NEWPIN. My early childhood experiences of growing up in an abusive family caused me to detach myself from any pain. Through the trauma of my childhood I became a very angry and unemotional girl, fighting anyone who stood in my way.

I left home at the age of 17 and moved in with a man. I was pregnant not long after I met him. I craved for this baby, someone to love me for who I was. I fantasised throughout my pregnancy about how much love I could give this child. Just like they show you on the TV. To my surprise all I could think about when I had her was if they put this baby on me I would be sick. I could not feel this love. I could not bond with her at all. My daughter was brought up the way my mother brought me up. I fed her, clothed her. kept her clean. But I never cuddled her. Never told her I loved her, never played with her. As she grew, so did my anger. I hated her. I blamed her for being alive. If it wasn't for her I could have died. She took away my dreams. Although I did overdose twice again. I was always left with a lot of guilt and shame from everyone around me. How could I even attempt to commit suicide with a baby that needed me so much? Little did they know about my life: I was the one who was needy, not her.

I gave birth to a second daughter. Don't ask me why. Maybe I felt I could get it right this time. I was further from the truth. Sometimes she would be naughty and hurt me. The only way I could deal with this was to hurt her back. I would reduce her to tears. I knew what I was doing was wrong, but I was out of control. I could only stop when I could see her pain. I was still so much a hurt child myself.

I can remember the first day I went to NEWPIN. I sat on a stool staring at everyone thinking you come near me and I will smash your face in'. I was only able to show anger. No one was going to break down my barriers. But eventually they did. I was scared at first and thought I could prove they did not really care about me. I again took an overdose and made sure the coordinator knew the next day. I was expecting her to judge me and tell me I was not welcome in NEWPIN anymore. But what I did get was 'Why didn't you phone me, I am here for you, I carell!' This was the turning point for me. I started to discover I could cry. I started receiving cuddles without anything else attached. I learnt how to show my feelings. To get support and being able to give it. I split up from my partner. I deserved better than the violence. I was involved in workshops and group therapy. It started to heal the hurt child within me. For the first time I felt like a human being. Loving my children did not come automatically, I learnt it over the next two years I was there.

I am now a coordinator myself after doing a further two years' training. My life is not perfect and I still make many mistakes, but my life has changed so much for the better. There is a world out there and I am part of it. It took me four years to build up trust with my children. I know I can't change what happened to me or what I have done to my children. but we do have a healthy future, together we are a team, my children are changing with me.

I know I will no longer suffer at the hands of someone else, and my children will no longer suffer at my hands. I am free from the pain. I am no longer a victim. I have broken the patterns. I have a life.

As Myra's story illustrates, there is no guarantee that each parent has the level of adult emotional maturity sufficient to protect and support her child from her previously damaged self. For a parent who as a child was subjected to significant levels of abuse and without recognisably consistent loving and validation, they may come to adulthood ill-equipped to supply their own child with the succour and containment needed for healthy emotional growth, self-worth and psychological maturation. Myra as a child coped with a consistently abusive childhood by splitting herself into two people. She says:

The person everyone saw and the person I felt inside...I learnt to detach myself from any pain. When I looked in the mirror I saw a different person. I became my heart and she became my brain. She was my only friend. I trusted her but we always argued. She was so much stronger than me. Because I was the heart I could feel pain... She was always logical.... and so through the trauma of my childhood I became a very angry and unemotional girl fighting anyone who stood in my way. By the time I was 13 years old my world seemed worse than going to hell. I had this fantasy that if I died I would go to a place where no pain is felt... This was when I started taking overdoses...I was thought of as being mad, bad and a disgrace to my family.

The fusion of her first daughter with herself and the resultant projection of hate and anger on to her is apparent from Myra's story. As long as this fusion continued she would even unwittingly put her own emotional needs first. That was how Myra had learned to survive.

What NEWPIN offered Myra was two-fold. At the centre she had the opportunity to behave naturally, she could see other parents with their children and she could place herself as to where she stood in her own eyes as a NEWPIN member. The opportunity to model on others through the living room and playroom was also part of her changing process. This freed her to begin to explore her childhood experiences. In an atmosphere which reinforced acceptance of her, thereby generating personal esteem, she was able to begin to separate herself psychically from her actual child. Second, through the personal development programmes and the therapeutic support group she was also able to change her perception about her own children and the requisite for benign mothering. She began to see her children as in need of cherishing support from herself as the responsible adult, and she could begin to see the value of childhood through their eyes.

The unique formula NEWPIN provides is that the mother works at the process of change simultaneously with, and alongside her children. which positively influences mutual emotional 
growth. The experience in conjunction with other mothers and their children provides, as one woman said, 'a real supportive family'. The outcome is an emotionally sustaining and longlasting chain reaction of nurture and positive responses.

\section{References}

Brown, G. W. \& Harris, T. (1978) The Social Origins of Depression. London: Tavistock.

JENKINS, A. (1996) NEWPIN: a creative mental health service for parents and children. In Parental Psychiatric Disorder (eds M. Göpfer, J. Webster \& M. V. Seeman). Cambridge: Cambridge Untversity Press.
Pound, A. (1990) The development of attachment in adult life - the NEWPIN experiment. British Joumal of Psychotherapy, 7, 77-85.

- (1994) NEWPIN - A Befriending and Therapeutic Network for Carers of Young Children. London: HMSO.

-. Mius, M.. PucKering. C.. et al (1991) Evaluation of a home visting and befriending scheme for young mothers: NEWPIN. Joumal of the Royal Society of Medicine. 84, 217-220.

Myra Gurr, NEWPIN Coordinator; and *Anne Hansen, Director National NEWPIN, Sutherland House, 35 Sutherland Square, Walworth, London SE17 3EE

*Correspondence

\section{Seminars in the Psychiatry of Learning Disabilities}

\section{Edited by Oliver Russell}

This volume is both an up to date account of recent advances in the field of learning disabilities and a practical guide to the diagnosis and treatment of psychiatric disorder. Chapters on the classification of psychiatric disorders in people with learning disabilities, the epidemiology of intellectual disability and the diagnosis of psychiatric disorder are followed by more detailed accounts of autism, behavioural phenotypes and communication disorders. Psychiatric disorders are covered in the latter part of the book, including discussions on behavioural interventions, counselling and epilepsy. The book concludes with a review of forensic aspects of psychiatric management and treatment. 1997, 288pp, ISBN 090124202 1, £15.00

The College Seminars Series and other Gaskell publications are available from Booksales, Publications Department, Royal College of Psychiatrists, 17 Belgrave Square, London SW1X 8PG (Tel. +44(0)171 235 2351, extension 146). The latest information on College publications is available on the INTERNET at: http://www.demon.co.uk/rcpsych/ 